OPEN ACCESS

Edited by:

Willy Bayuardi Suwarno,

Bogor Agricultural

University, Indonesia

Reviewed by:

Tahira Fatima,

Purdue University, United States

Martin Broadley,

University of Nottingham,

United Kingdom

*Correspondence:

Abdul Rehman

abdurehmanuaf@gmail.com

Specialty section:

This article was submitted to

Crop Biology and Sustainability,

a section of the journal

Frontiers in Sustainable Food Systems

Received: 05 August 2020 Accepted: 30 November 2020 Published: 22 December 2020

Citation:

Rehman A, Farooq M, Ullah A Nadeem F, Im SY, Park SK and

Lee D-J (2020) Agronomic Biofortification of Zinc in Pakistan: Status, Benefits, and Constraints. Front. Sustain. Food Syst. 4:591722.

doi: 10.3389/fsufs.2020.591722

\section{Agronomic Biofortification of Zinc in Pakistan: Status, Benefits, and Constraints}

\author{
Abdul Rehman ${ }^{1 *}$, Muhammad Farooq ${ }^{2,3}$, Aman Ullah ${ }^{2}$, Faisal Nadeem ${ }^{4}$, Seon Young Im $^{1}$ \\ Sang Koo Park ${ }^{5}$ and Dong-Jin Lee ${ }^{1}$ \\ ${ }^{1}$ Department of Crop Science and Biotechnology, Dankook University, Chungnum, South Korea, ${ }^{2}$ Department of Plant \\ Sciences, College of Agricultural and Marine Sciences, Sultan Qaboos University, Al-Khoud, Oman, ${ }^{3}$ Department of \\ Agronomy, University of Agriculture, Faisalabad, Pakistan, ${ }^{4}$ Department of Agronomy, The University of Haripur, Haripur, \\ Pakistan, ${ }^{5}$ Food Safety Management Division, Regional Korea Food and Drug Administration, Seoul, South Korea
}

Micronutrient malnutrition (e.g., zinc) is one of the major causes of human disease burden in the developing world. Zinc (Zn) deficiency is highly prevalent in the Pakistani population (22.1\%), particularly in women and children (under 5 years) due to low dietary Zn intake. In Pakistan, wheat is the primary staple food and is poor in bioavailable Zn. However, the number of malnourished populations has decreased over the last decade due to multiplied public awareness, accelerated use of Zn fertilizers (particularly in wheat and rice), initiation of several national/international research initiatives focusing on $\mathrm{Zn}$ biofortification in staple crops and availability of supplements and $\mathrm{Zn}$ fortified meals merchandise, nonetheless a large number of people are facing Zn or other micronutrient deficiencies in the country. There are few reports highlighting the significant increase in daily dietary Zn uptake in population consuming biofortified wheat (Zincol-2016) flour; indicating the positive prospect of biofortification interventions up scaling in lowering the risk of dietary Zn deficiency in rural and marginalized communities. Zinc fertilizer strategy has not only helped in enhancing the grain Zn concentration, but it also helped in improving crop yield with high economic return. In addition, Zn biofortified seeds have exhibited strong inherent ability to withstand abiotic stresses and produce higher grain yield under diverse climatic conditions. However, there are many constraints (soil, environment, genetic diversity, antinutrients concentration, socioeconomic factors etc.) that hinder the success of biofortification interventions. This review highlights the status of Zn deficiency in Pakistan, the success of agronomic and genetic biofortification interventions. It also discusses the economics of agronomic biofortification and cost effectiveness of $\mathrm{Zn}$ fertilization in field conditions in Pakistan and the potential of $\mathrm{Zn}$ biofortified seeds against abiotic stresses. Furthermore, it also highlights the constraints which limit the sustainability of biofortification interventions. 


\section{INTRODUCTION}

Micronutrient malnutrition is an eminent problem globally. Many people do not have access to "healthy and nutritious food" to carry out a healthy lifestyle. The daily $\mathrm{Zn}$ requirement of adult and pregnant/lactating women ranges from 8 to $11 \mathrm{mg}$ and 11 to $13 \mathrm{mg}$, respectively (Bhowmik et al., 2010); while, $8-18 \mathrm{mg} /$ day daily iron $(\mathrm{Fe})$ intake is recommend depending on age, gender and body weight, and $27 \mathrm{mg} /$ day $\mathrm{Fe}$ intake is advised for pregnant women [National Institutes of Health (NIH), 2019]. The deficiency of any of the essential micronutrient can disrupt the plant growth and causes significant yield losses (Tripathi et al., 2015), as they have very important roles and metabolic functions in plants. Zinc is a vital microelement and its deficiency is highly widespread in plants and humans (Cakmak and Kutman, 2018; Rehman et al., 2018a). Consumption of low $\mathrm{Zn}$ diets instigates the $\mathrm{Zn}$ deficiency in human body. Cereals are poor in bioavailable $\mathrm{Zn}$ and consumption of cereals-based diets is amongst the leading causes of dietary $\mathrm{Zn}$ deficiency disorder in developing countries like Pakistan (Cakmak and Kutman, 2018; Rehman et al., 2018a,b,c,d). Soil and plant $\mathrm{Zn}$ deficiency represents major micronutrient disorder in $>40$ countries affecting almost $1 / 3$ rd of agricultural soils globally (Alloway, 2008). In Pakistan, rice and wheat growing soils are deficient in major micronutrients including $\mathrm{Zn}$ and boron (B), manganese $(\mathrm{Mn})$, iron $(\mathrm{Fe})$, copper $(\mathrm{Cu})$, and molybdenum $(\mathrm{Mo})$ (Rehman et al., 2018a; Nadeem and Farooq, 2019). In Southern Punjab more than $70 \%$ of wheat cultivated soils are deficient in plant available Zn (Maqsood et al., 2015). Similarly, the soils of pulses growing areas are also deficient in plant available $\mathrm{Zn}$ (Maqsood et al., 2015; Ullah et al., 2020a,b).

Zinc plays many essential roles in reproductive health, immune system functioning, neurotransmission, intestine signaling, and body growth (Herschfinkel et al., 2007; Wessels and Rink, 2020). Therefore, $\mathrm{Zn}$ deficiency is associated with several health problems such as impaired learning, abnormal immune system, increased infection rate, and impaired physical growth (Gibson, 2006; Prasad, 2007; Wessels and Rink, 2020). Malnutrition is a global issue as nearly $1 / 4$ th of world population is suffering from one or more micronutrient malnutrition disorders (Kumssa et al., 2015). The issue of malnutrition is high in the world and progress made to overcome this problem is still at a slow pace. Around the world, $149 \mathrm{M}(21.9 \%)$ children are stunted, $49.5 \mathrm{M}$ (7.3\%) wasted, and $40.1 \mathrm{M}(5.9 \%)$ overweight due to multifaceted malnutrition (UNICEF, 2020). In South Asia, $60-70 \%$ of people are $\mathrm{Zn}$ deficient (Gibson, 2006), and it is one of the leading causes of stunted growth in children globally. In Pakistan, $12 \mathrm{M}$ children are stunted and $22.1 \%$ of women and $18.6 \%$ of children (under- age of five) are $\mathrm{Zn}$ deficient. In the case of $\mathrm{Zn}$ deficiency in women, Punjab has the highest share (24.1\%), followed by Balochistan (23.4\%), and Sindh (21.4\%), while, Khyber Pakhtunkhwa has lowest prevalence (15.9\%) (Ministry of National Health Services Nutrition Wing, 2018).

In Pakistan, wheat, and rice are consumed in a grater quantity to fulfill the daily food requirement. The higher concentrations of $\mathrm{Zn}$ and other micronutrients are present in germ and aleurone of wheat and these constituents only $\sim 20 \%$ of the total seed and are usually removed during milling leaving the starchy endosperm having low $\mathrm{Zn}$ concentration. Human $\mathrm{Zn}$ deficiency can be reduced through fortification ( $\mathrm{Zn}$ enrichment of food products during processing) or supplementation but these are expensive and not sustainable approaches. Nevertheless, biofortification is a viable and economical method to reduce the $\mathrm{Zn}$ nutritional disorder and to improve the bioavailable $\mathrm{Zn}$ in edible plant parts (Farooq et al., 2018; Ullah et al., 2020a). Genetic (conventional or molecular breeding and transgenic techniques) or agronomic approaches including suitable soil and plant fertilizer application are the major interventions for $\mathrm{Zn}$ biofortification of food crops (Cakmak and Kutman, 2018). Agronomic biofortification not only improves crop growth but also increases the crops' micronutrient mobilization and utilization potential (Zuo and Zhang, 2009; Hussain et al., 2012a; Cakmak and Kutman, 2018; Rehman et al., 2018b,c,d). Bouis and Saltzman (2017) reported that biofortified crops are produced and consumed by over $20 \mathrm{M}$ people globally. The deficiency of micronutrients can be corrected by delivery of these microelements via soil, leaf, and seed treatments. The significant improvements in grain nutrients and grain yields have been reported in Pakistan and around the world due to these approaches in both cereals and legumes.

Many review articles have reported the biofortification interventions on cereals and legumes in developing countries (Cakmak, 2008; Rehman et al., 2018a; Ullah et al., 2020a). Nevertheless, this is the first review that describes the progress on $\mathrm{Zn}$ biofortification interventions in cereals and legumes in Pakistan. It further highlights the status of genetic and agronomic biofortification, benefits and economics of agronomic biofortification related to crop productivity in field conditions. It also highlights the constraints to the agronomic biofortification interventions in Pakistan.

\section{BENEFITS OF ZINC BIOFORTIFICATION}

Zinc fertilization through either method (soil, leaf, or seed treatments) is aimed to enhance the plant $\mathrm{Zn}$ uptake (Farooq et al., 2012; Rehman and Farooq, 2016; Rehman et al., 2018b,c). In Pakistan, the agronomic biofortification approach has been successful in improving the grain $\mathrm{Zn}$ concentration, crop productivity, and profitability (Tables 1, 2; Rehman et al., 2018a,b,d; Ullah et al., 2019, 2020c,d,e). The agronomic Zn biofortification not only increases the grain Zn bioavailability but it also improves the net economic return with higher grain yield and saves billions of USD by limiting the risk of Zn deficiency.

The agronomic positive effect of $\mathrm{Zn}$ fertilization results in improved $\mathrm{Zn}$ bioavailability in the human digestive tract (Table 1; Rehman et al., 2018b,c,d). It is noted that enhancing the nutrient concentration in the whole plant or seed is not adequate as the element should be translocated to the edible part of the grain (e.g., endosperm) and must be bioavailable. Phytate is antinutrient and inhibits the $\mathrm{Zn}$ bioavailability to the human body; therefore, the $\mathrm{Zn}: \mathrm{PA}$ molar ratio in the edible seed part is an important indicator of $\mathrm{Zn}$ bioavailability. Phytate is usually present in higher concentrations in aleurone and germ in cereals; while very low phytate is present in the 
TABLE 1 | Increase in grain Zn concentration and bioavailable Zn in different cereal and grain legume crops with Zn application.

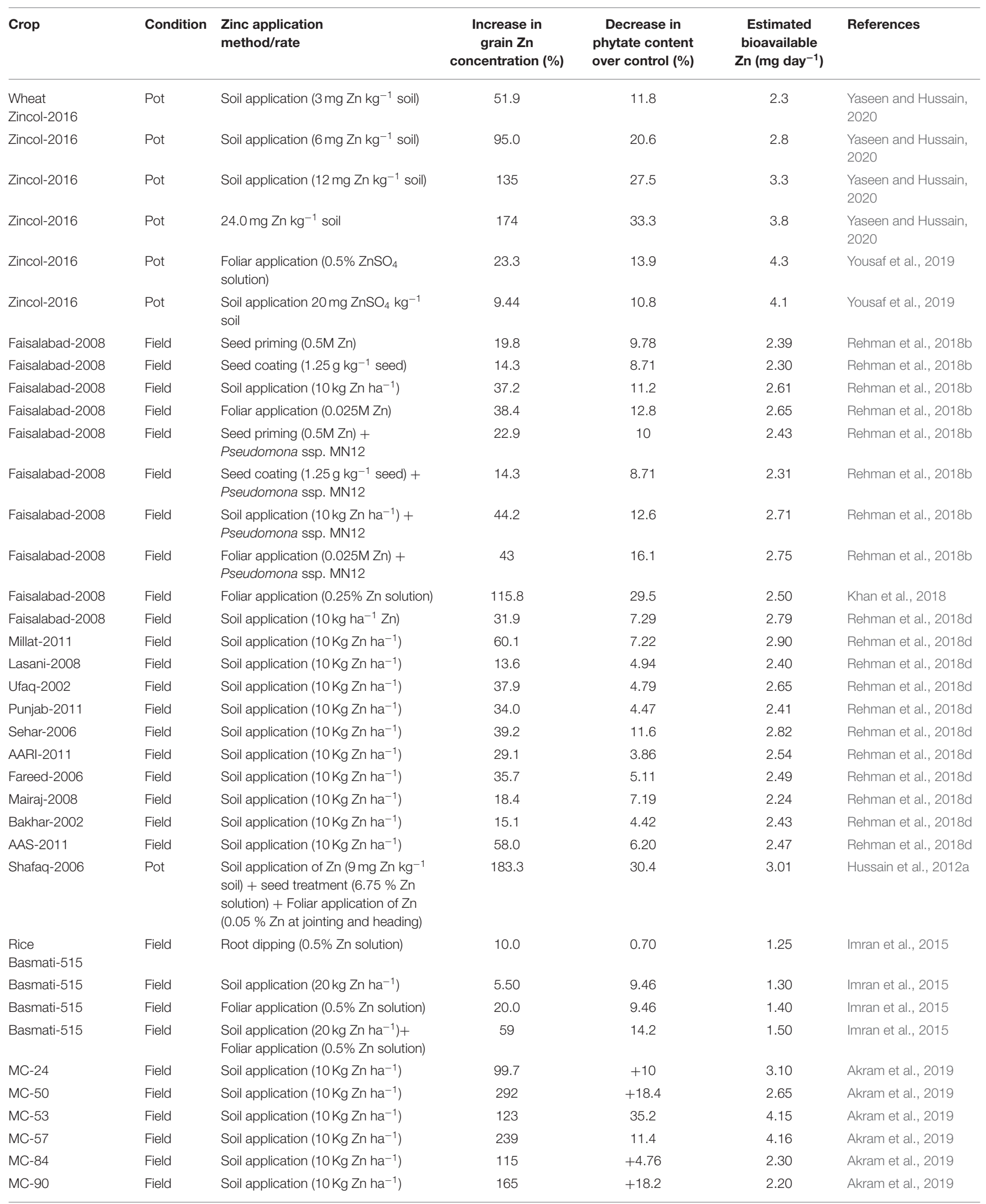


TABLE 1 | Continued

\begin{tabular}{|c|c|c|c|c|c|c|}
\hline Crop & Condition & $\begin{array}{l}\text { Zinc application } \\
\text { method/rate }\end{array}$ & $\begin{array}{c}\text { Increase in } \\
\text { grain } \mathrm{Zn} \\
\text { concentration (\%) }\end{array}$ & $\begin{array}{c}\text { Decrease in } \\
\text { phytate content } \\
\text { over control (\%) }\end{array}$ & $\begin{array}{c}\text { Estimated } \\
\text { bioavailable } \\
\text { Zn }\left(\mathrm{mg} \mathrm{day}^{-1}\right)\end{array}$ & References \\
\hline MC-95 & Field & Soil application (10 Kg Zn ha-1) & 180 & +29.7 & 2.90 & Akram et al., 2019 \\
\hline MC-98 & Field & Soil application (10 Kg Zn ha-1) & 303 & 13.6 & 4.27 & Akram et al., 2019 \\
\hline MC-101 & Field & Soil application (10 Kg Zn ha-1) & 156 & 10.0 & 4.00 & Akram et al., 2019 \\
\hline MC-109 & Field & Soil application (10 Kg Zn ha-1) & 142 & 21.9 & 2.90 & Akram et al., 2019 \\
\hline $\begin{array}{l}\text { Chickpea } \\
\text { (NIAB-CH-2016) }\end{array}$ & Field & Soil application (10 Kg Zn ha-1) & 25.3 & 29.5 & 4.37 & Ullah et al., 2020d \\
\hline NIAB-CH-2016 & Field & Seed coating ( $\left.5 \mathrm{mg} \mathrm{kg} \mathrm{seed}^{-1}\right)$ & 22.0 & 23.1 & 4.23 & Ullah et al., 2020d \\
\hline NIAB-CH-2016 & & Seed priming (0.001 M Zn) & 10.6 & 15.0 & 3.98 & Ullah et al., 2020d \\
\hline NIAB-CH-2016 & & Foliar application (0.025 M) & 9.24 & 17.3 & 3.99 & Ullah et al., 2020d \\
\hline Noor2013 & Field & Seed coating ( $\left.5 \mathrm{mg} \mathrm{ha}^{-1}\right)$ & 17.2 & 35.2 & 4.64 & Ullah et al., 2020e \\
\hline Noor2013 & Field & Osmopriming (0.001 M Zn solution) & 11.9 & 20.7 & 4.38 & Ullah et al., $2020 \mathrm{e}$ \\
\hline
\end{tabular}

endosperm (reviewed in Gupta et al., 2016). Therefore, higher Zn translocation in the endosperm increases the $\mathrm{Zn}$ bioavailability. In different pot and field studies, Rehman et al. (2018b,c,d) demonstrated that $\mathrm{Zn}$ application through soil, leaf, or seed treatments enhances the $\mathrm{Zn}$ concentration in whole grain and seed fractions (endosperm, aleurone, and germ) of wheat and reduces the phytate accumulation and enhanced the bioavailable $\mathrm{Zn}$ concentration ( $>3 \mathrm{mg} \mathrm{Zn} \mathrm{day}{ }^{-1}$ ) (Table 1). Hussain et al. (2012a) also testified that soil $\mathrm{Zn}$ fertilization enhances the $\mathrm{Zn}$ concentration and bioavailability in wheat grain by 95 and $74 \%$ respectively, and substantially reduce the phytate accumulation in grain. Recently, Nadeem et al. (2020a) demonstrated that soil $\mathrm{Zn}$ application improved grain quality and grain $\mathrm{Zn}$ enrichment of wheat. They further reported the residual effect of soil applied $\mathrm{Zn}$ in the succeeding wheat crop with an increase of 72 and 59\% in grain $\mathrm{Zn}$ concentration during both years, respectively. Yaseen and Hussain (2020) evaluated the effect of soil Zn fertilization on a standard and a Zn biofortified wheat cultivar (Zincol-2016) in a glasshouse experiment, and narrated that soil $\mathrm{Zn}$ application (6 mg Zn kg-1 soil) to Zincol-2016 (wheat cultivar having high intrinsic $\mathrm{Zn}$ concentration) augmented the $\mathrm{Zn}$ concentration by $53 \mathrm{mg} \mathrm{kg}{ }^{-1}$ in wheat grain and also enhanced the estimated bioavailable $\mathrm{Zn}\left(\sim 3 \mathrm{mg} \mathrm{d}^{-1}\right)$; while standard wheat cultivar had maximum grain $\mathrm{Zn}$ accumulation at plant toxic rate of soil $\mathrm{Zn}$ application (24 $\mathrm{mg} \mathrm{Zn} \mathrm{kg}^{-1}$ ).

A recent survey of adults consuming wheat flour from $\mathrm{Zn}$ treated (soil application of $3.7 \mathrm{~kg} \mathrm{Zn} \mathrm{ha}^{-1}$ ) or controlled fields (no $\mathrm{Zn}$ application) revealed that rural population consuming agronomically biofortified $\mathrm{Zn}$ flour had significantly higher daily dietary $\mathrm{Zn}$ intake and estimated bioavailable $\mathrm{Zn}$ with reduction in daily phytate intake compared to control group. Moreover, among the gender and age group, the increase was higher in adult and men compared to older adults and women, respectively (Ahsin et al., 2020). Likewise, soil application of $\mathrm{ZnO}$ nanoparticles substantially enhanced the $\mathrm{Zn}$ accumulation at both vegetative and reproductive growth stages, leading to higher grain $\mathrm{Zn}$ concentration (59\%) and yield of maize grown under glasshouse and field conditions (Umar et al., 2020). Akram et al. (2019) demonstrated that soil application of $\mathrm{Zn}(10 \mathrm{~kg}$ $\mathrm{ha}^{-1}$ ) enhanced the grain $\mathrm{Zn}$ concentration, $\mathrm{Zn}$ bioavailability $\left(4.27 \mathrm{mg} \mathrm{d}^{-1}\right)$, and reduced the phytate accumulation $(-32.6 \%)$ in rice grains.

In legumes, phytate concentration is lower than cereals but it is uniformly distributed throughout the seed. Zinc fertilization has proved effective in enhancing the grain $\mathrm{Zn}$ concentration and estimated bioavailable $\mathrm{Zn}$ in legumes (Table 1). In a recent field study, Ullah et al. (2020d) demonstrated that $\mathrm{Zn}$ application through seed treatments, soil, and foliar application in combination with plant growth promoting bacteria (PGPB) limited the grain phytate accumulation, and enhanced the grain $\mathrm{Zn}$ concentration and estimated bioavailable $\mathrm{Zn}$ (3.99-4.45 mg $\mathrm{Zn}$ day $^{-1}$ ) in desi chickpea. Likewise, Rasheed et al. (2020) applied soil $\mathrm{Zn}$ to 16 lentil genotypes and found that soil $\mathrm{Zn}$ (9 $\mathrm{mg} \mathrm{Zn} \mathrm{kg}^{-1}$ soil) application substantially fostered the grain $\mathrm{Zn}$ concentration and estimated bioavailable $\mathrm{Zn}(2.17-2.97 \mathrm{mg}$ day $^{-1}$ ) in tested lentil genotypes.

Zinc fertilizer application enhances the $\mathrm{Zn}$ translocation to the cereals endosperm and help in reducing the $\mathrm{Zn}$ deficiency risk in consumer due to increase $\mathrm{Zn}$ bioavailability (Joy et al., 2015; Rehman et al., 2018a,b,c,d). The economic viability of agronomic biofortification is imperative for the sustainability of this strategy and is usually measured in disability adjusted life years (DALYs), which estimates the disease burden based on its mortality and morbidity and quantify the public health strategies on their cost effectiveness (Rehman et al., 2018a). According to a recent estimate, the agronomic biofortification intervention can help in saving and reducing the dietary $\mathrm{Zn}$ deficiency risk and decrease the DALYs loss by 30,000 and 80,000 in Sindh and Punjab province. The average value of one DALYs is 416-619 USD and 292-370 USD in Punjab and Sindh, respectively, which can limit the disease burden by 155 and 405 M USD in Sindh and Punjab, respectively (Joy et al., 2017). According to world health organization, $\mathrm{Zn}$ biofortification can help in saving the 3 billion USD annually ${ }^{1}$ and is cost

${ }^{1}$ www.harvestplus.org. Harvest Plus Pakistan. Available online at: https://www. harvestplus.org/where-we-work/pakistan (accessed 31 July, 2020). 
TABLE 2 | Economics of Zinc applications in different field crops in Pakistan.

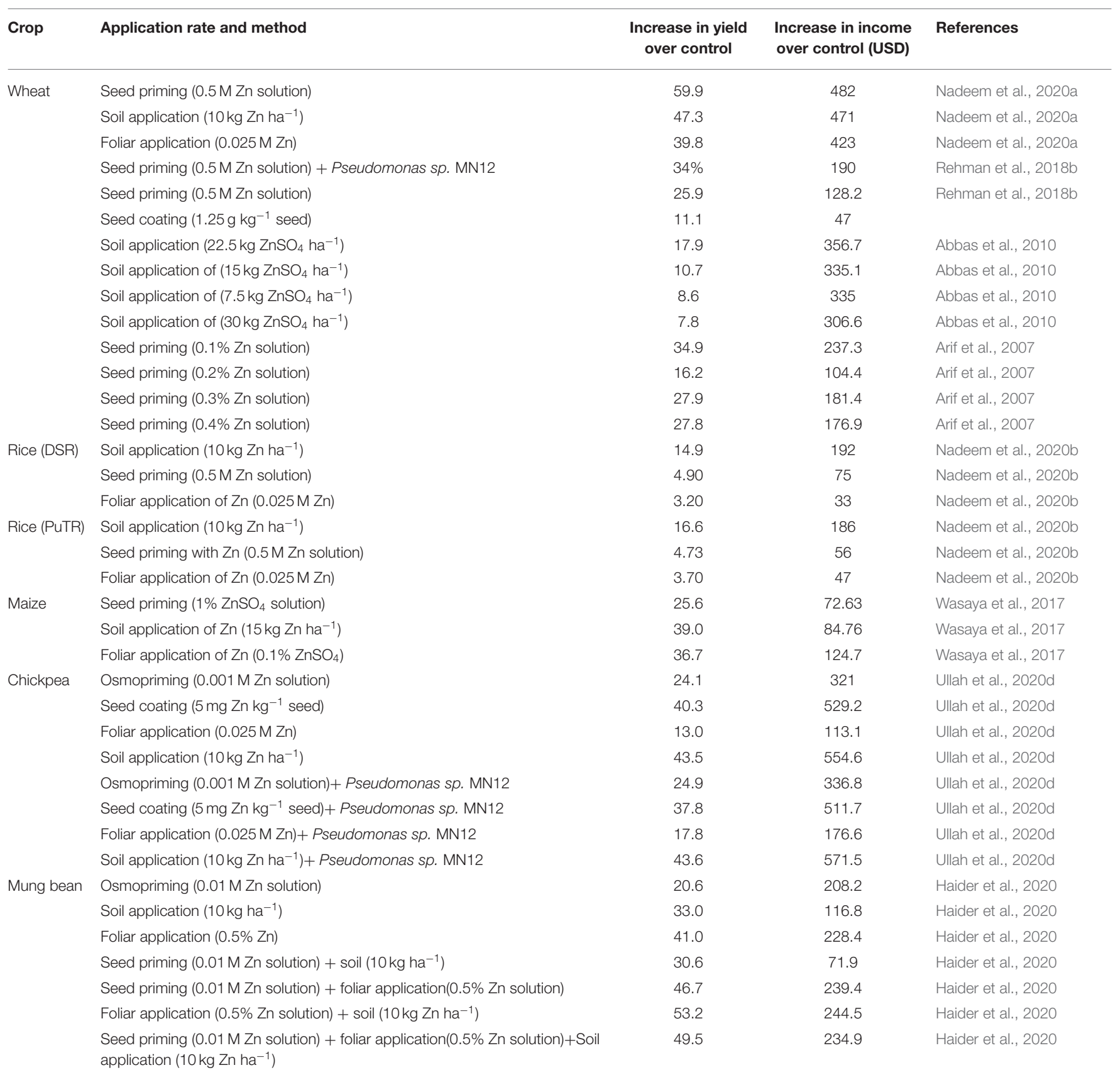

DSR, direct seeded aerobic rice; PUTR, Puddled transplanted rice.

effective strategy in Pakistan according to WHO standards (Joy et al., 2017).

Agronomic $\mathrm{Zn}$ biofortification not only helps in reducing the dietary $\mathrm{Zn}$ deficiency but it also improves the crop yield and productivity. Zinc fertilization using different methods and sources is aimed to enhance the plant $\mathrm{Zn}$ uptake which leads to better plant growth, grain $\mathrm{Zn}$ biofortification, yield, and economic returns. In Pakistan, several field studies have reported the increase in grain yield and economic returns with agronomic $\mathrm{Zn}$ biofortification in cereals and legumes (Table 2; Arif et al., 2007; Farooq et al., 2018; Rehman et al., 2018b; Ullah et al., 2019, 2020a,d; Nadeem et al., 2020a,b). Rehman et al. (2018b) found that seed priming with $\mathrm{Zn}$ using $\mathrm{Zn}$ solubilizing PGPB in wheat enhanced the grain $\mathrm{Zn}$ concentration, grain yield with the highest benefit cost ratio (BCR) (1.59) and net benefit of $506 \mathrm{USD} \mathrm{ha}^{-1}$. Likewise, in a recent study, Ullah et al. (2020d) reported higher improved grain yield, grain $\mathrm{Zn}$ concentration, and high BCR (4.05) and economic returns of 1,518 USD ha ${ }^{-1}$ in desi chickpea with soil $\mathrm{Zn}$ application in combination with PGPB.

Similarly, soil $\mathrm{Zn}$ application to wheat grown in conventional and conservation rice-wheat cropping system substantially improved grain $\mathrm{Zn}$ biofortification, seed yield, with higher 
BCR (2.23) and economic returns of $973 \mathrm{USD} \mathrm{ha}^{-1}$ (Nadeem et al., 2020a). In another study, Nadeem et al. (2020b) reported that residual $\mathrm{Zn}$ applied to wheat improves the grain $\mathrm{Zn}$ concentration and yield of succeeding rice crop in conservation rice-wheat cropping system. They further reported high BCR and economic returns (877 $\mathrm{USD} \mathrm{ha}^{-1}$ ) with soil $\mathrm{Zn}$ fertilization. In several field studies, $\mathrm{Zn}$ delivery through seed treatments (seed priming and seed coating) have reported better grain yield and high economic returns compare to soil and foliar $\mathrm{Zn}$ application under diverse soil and climatic conditions (Arif et al., 2007; Farooq et al., 2018; Rehman et al., 2018a,b; Ullah et al., 2020d). However, seed treatments are less effective in improving grain Zn concentration (Farooq et al., 2018; Yousaf et al., 2019). For instance, Farooq et al. (2018) demonstrated in a field study at different locations in RWCS of Punjab that Zn application through either method (soil application, seed treatment, and foliar spray) increased the paddy yield and economic return in both puddled and transplanted rice. However, seed coating did not enhance the grain $\mathrm{Zn}$ concentration (Farooq et al., 2018). Seed treatments are more economical than other $\mathrm{Zn}$ fertilizer application methods due to low cost of applied fertilizer (very small quantity is need) and better crop stand due to increased availability of $\mathrm{Zn}$ during early stages of plant growth (Farooq et al., 2012). In $\mathrm{Zn}$ deficient salt affected or drought stress soils, seed priming is better method of $\mathrm{Zn}$ delivery compare to soil $\mathrm{Zn}$ application.

The increase use of $\mathrm{Zn}$ fertilizers can help in gaining higher monetary benefits to the farmers as recently, Joy et al. (2017) projected the potential economic benefits with agronomic $\mathrm{Zn}$ biofortification in wheat and reported that $\mathrm{Zn}$ fertilizer application can boost wheat yield 0.6-3.1 Mt year ${ }^{-1}$ with an average increase of 0.4 and $0.34 \mathrm{t} \mathrm{ha}^{-1}$ in Sindh and Punjab respectively. The monetarist benefits of $\mathrm{Zn}$ fertilizer application in wheat are estimated to be 200 and $700 \mathrm{M}$ USD in Sindh and Punjab, respectively. In conclusion, agronomic $\mathrm{Zn}$ biofortification not only enhances the grain $\mathrm{Zn}$ enrichment but also augments the crop productivity through increased yield with high monetary benefits.

Seedling vigor and growth during the early crop development stage are strongly linked with the inherent seed $\mathrm{Zn}$ level (review in Rehman et al., 2018a). Improving the seed $\mathrm{Zn}$ enrichment through $\mathrm{Zn}$ fertilization enhances the crop performance, and yield in succeeding crop (Yilmaz et al., 1998; Faran et al., 2019; Farooq et al., 2020). Therefore, agronomic biofortification can help in improving the crop performance on $\mathrm{Zn}$ deficient soils or soils having suboptimal growth conditions (arid or salt affected soils) (Rehman et al., 2018a). In Pakistan, we conducted several studies regarding the role of intrinsic $\mathrm{Zn}$ concentration in environmental stress tolerance in wheat. In one of our pot studies, we used biofortified wheat seed having high intrinsic $\mathrm{Zn}\left(49 \mathrm{mg} \mathrm{kg}^{-1}\right)$ and found that wheat plants grown from high intrinsic Zn seed performed better under different abiotic stresses (drought, waterlogging, and salinity) (Faran et al., 2019).

The plants originated from seed having a high $\mathrm{Zn}$ level had lower oxidative damage, better antioxidant capacity, higher seed yield, and had more $\mathrm{Zn}$ concentration (21-48\%) compared to plant grown from low Zn seeds (Faran et al., 2019). Cultivation of
Zn biofortified wheat having high intrinsic $\mathrm{Zn}$ concentration can also help in alleviating the adverse effects of heavy metal stress on plant growth. Recently, Farooq et al. (2020) reported that soil $\mathrm{Zn}$ application integrated with biochar using high intrinsic $\mathrm{Zn}$ seed improved the productivity and grain $\mathrm{Zn}$ concentration and decreased the Cd uptake in Cd contaminated soil compared to control or plants grown from low $\mathrm{Zn}$ seeds. In a pot study, Qaswar et al. (2017) grown Zincol-2016 (biofortified wheat cultivar) and standard wheat cultivar (Faisalabad-2008) on heavy metal contaminated soil. They found that biofortified wheat cultivar accumulated more $\mathrm{Zn}$ and heavy metals (Pd and Cd). However, $\mathrm{Zn}$ fertilization reduced the $\mathrm{Pd}$ and $\mathrm{Cd}$ uptake and translocation in grain compared to standard wheat cultivar. Rashid et al. (2019) reported an increase in seedling emergence, population density, grain yield and seed $\mathrm{Zn}$ concentration with $\mathrm{Zn}$ biofortified seeds (50 $\mathrm{mg} \mathrm{kg}^{-1}$ ) under diverse soil and climatic conditions. Zinc biofortified seeds are by product of $\mathrm{Zn}$ biofortification and the use of high intrinsic $\mathrm{Zn}$ seeds is a costeffective strategy and improves crop productivity. Moreover, $\mathrm{Zn}$ biofortified seeds are more tolerant to environmental stresses and can help in successful crop production on diverse soil and climatic conditions.

\section{STATUS OF ZINC BIOFORTIFICATION}

According to the 2011 national survey of nutrition, the $\mathrm{Zn}$ deficiency was 47.6 and $41.3 \%$ in pregnant and non-pregnant women, while $39.2 \%$ children were suffering from $\mathrm{Zn}$ deficiencies [Government of Pakistan (GOP), 2011]. However, in a recent report by the national nutritional survey, the deficiency of $\mathrm{Zn}$ has decreased to 22.1 and $18.6 \%$ in women and children, respectively (Ministry of National Health Services Nutrition Wing, 2018). This decrease in $\mathrm{Zn}$ malnourished population is outcome of several factors including public awareness through electronic and print media, farmers training and awareness ( $\mathrm{Zn}$ fertilizers applications in wheat \& rice), increased availability of $\mathrm{Zn}$ fortified food products and supplements in the market and initiation of projects like "Harvest plus" and "BiZiFED" which are focused to reduce the micronutrient disorders in staple food crops. The projected dietary Zn supply in Punjab (12.6 mg capita ${ }^{-1} \mathrm{~d}^{-1}$ ) and Sindh (12.6 mg capita ${ }^{-1} \mathrm{~d}^{-1}$ ) would increase to $14.5 \mathrm{mg}$ capita $^{-1} \mathrm{~d}^{-1}$ with increased use of $\mathrm{Zn}$ fertilizer in wheat (Joy et al., 2017).

The baseline $\mathrm{Zn}$ fertilizer $\left(\mathrm{ZnSO}_{4} \cdot \mathrm{H}_{2} \mathrm{O}\right)$ use in Pakistan according to industry and published data source is $7.3 \mathrm{kt} \mathrm{y}^{-1}$ (Joy et al., 2017). The increase in grain yield of $8 \%$ (Punjab) and $14 \%$ (Sindh) were reported with $\mathrm{Zn}$ fertilizers use in wheat areas (survey of $>2,500$ farmers) (Joy et al., 2017). The Consultative Group on International Agricultural Research (CGIAR) initiated the Harvest plus challenge program on "Biofortified Crops for Improved Human Nutrition" with funding from Bill and Melinda Gates Foundation, the World Bank, and USAID in 2004. The target of this program was to enhance the micronutrients ( $\mathrm{Zn}, \mathrm{Fe}$, and vitamin A) level in staple food crops of the developing world. This program has seven target crops which are staple in developing countries. In Pakistan, this program was 
focused to develop "nutrient dense wheat genotypes" as wheat which is the primary staple food crop of the country and is low in micronutrients particularly $\mathrm{Zn}$ and Fe. The Harvest plus target of wheat grain $\mathrm{Zn}$ concentration is $37 \mathrm{mg} \mathrm{kg}^{-1}$ (Bouis and Saltzman, 2017). Pakistan Agriculture Research Council (PARC) with the collaboration of Harvest plus and International Maize and Wheat Improvement Centre (CIMMYT) has developed the first $\mathrm{Zn}$ wheat cultivar Zincol-2016 having grain $\mathrm{Zn}$ concentration of $\sim 37 \mathrm{mg} \mathrm{kg}^{-1}$ (http://www.parc.gov.pk/index.php/en/wheatachievements) which is $30 \%$ more than most of the cultivated wheat varieties in Pakistan (Hussain et al., 2012b; Rehman et al., $2018 \mathrm{~d}$ ) and is being consumed by $\sim 0.2 \mathrm{M}$ households.

Harvest plus is supporting PARC and National Agricultural Research Centre (NARC) to develop more Zn dense wheat cultivars with high yield potential. The work on biofortification of $\mathrm{Zn}$ dense cereals (rice and wheat) and legumes (lentil and chickpea) is being carried out in different universities and research organizations across Pakistan. Harvest plus is a partner with several public universities, research institutes, and private companies for seed multiplication, research, and development ${ }^{1}$. The use of transgenes has also shown promising results in enhancing the $\mathrm{Zn}$ bioavailability. Abid et al. (2017) demonstrated that wheat plants showing overexpression of Aspergillus japonicus gene "phy $A$ " exhibited high phytase activity and enhanced $\mathrm{Zn}$ bioavailability in wheat endosperm. Moreover, many studies have reported the genetic diversity for grain $\mathrm{Zn}$ concentration in cereals (Hussain et al., 2012b; Rehman et al., 2018d) and legumes (Rasheed et al., 2020; Ullah et al., 2020c).

The Biotechnology and Biological Sciences Research Council (BBSRC), Global Challenges Research Fund (GCRF) has also launched the project "The Biofortified Zinc Flour to Eliminate Deficiency (BiZiFED) in Pakistan” from 2017 to 2019 to address the issue of $\mathrm{Zn}$ deficiency. The programme is working (i) to evaluate the role of Zincol-2016 in improving the $\mathrm{Zn}$ and $\mathrm{Fe}$ status in children and girls living in low resource communities (ii) spatial modeling using soil and crop data to predict the grain $\mathrm{Zn}$ concentration variations due to soil properties and farm management practices, and (iii) to study the socio economic and market constraints in uptake of biofortified wheat cultivars. The BiZiFED project survey reported that more than half of the females were $\mathrm{Zn}$ deficient from the randomized controlled trial (Ohly et al., 2019). In Pakistan, the research on agronomic biofortification interventions to enhanced grain $\mathrm{Zn}$ deposition and bioavailability in cereals (wheat and rice) has been done by many scientists (Hussain et al., 2012a,b; Farooq et al., 2018; Rehman et al., 2018b,c,d; Rashid et al., 2019; Nadeem et al., 2020a,b). However, recently, the research on legumes (chickpea and lentil) biofortification has also got attention (Rasheed et al., 2020; Ullah et al., 2020a,c,d,e). Farooq and colleagues have optimized several seed treatments (seed coating and seed priming) protocols for micronutrients delivery in rice, wheat, and chickpea along with soil and foliar fertilization in both Laboratory and field environments (Rehman et al., 2015, 2018b,c,d; Rehman and Farooq, 2016; Ullah et al., 2019, 2020a,c,d,e). The seed treatments along with foliar and soil $\mathrm{Zn}$ application proved effective in enhancing the productivity and grain $\mathrm{Zn}$ concentration in tested crops. Further, the PGPB ( $\mathrm{Zn}$ solubilizing) alone and in combination with soil application, foliar spray, and seed treatments has also proved effective in enhancing the seed $\mathrm{Zn}$ accumulation and bioavailability.

\section{CONSTRAINTS}

\section{Low Genetic Diversity and High Phytate}

Breeding approach focusing on the development of new crop genotypes with high grain $\mathrm{Zn}$ concentration, firstly requires the presence of valuable genetic variation among selected germplasm for grain nutrient accumulation (White and Broadley, 2005; Rehman et al., 2018a; Ludwig and Slamet-Loedin, 2019). Hussain et al. (2012b) in a field study reported that grain $\mathrm{Zn}$ concentration in 65 wheat genotypes developed after the green revolution ranged from 24 to $36 \mathrm{mg} \mathrm{kg}^{-1}$. However, the grain phytate and bioavailable $\mathrm{Zn}$ ranged from 7.1 to $11.1 \mathrm{mg}$ $\mathrm{g}^{-1}$ and 1.52 to $2.15 \mathrm{mg} \mathrm{Zn}$ day $^{-1}$ respectively. Later, Rehman et al. (2018d) investigated the pool of 28 wheat genotypes (under field conditions) developed in Pakistan and found very low genetic diversity among the tested genotypes and only two genotypes "Fareed-2006" and "GA-02" exhibited maximum genetic diversity, which is the result of inbreeding and sharing common gene pool. Moreover, the tested genotypes have grain Zn concentration from 21.2 to $33.3 \mathrm{mg} \mathrm{kg}^{-1}$; while grain phytate and bioavailable $\mathrm{Zn}$ concentration ranged from 7.15 to $10.3 \mathrm{mg}$ $\mathrm{g}^{-1}$ and 1.74 to $2.47 \mathrm{mg} \mathrm{Zn} \mathrm{day}^{-1}$ respectively. The seed fraction analysis of wheat genotypes of Pakistani origin revealed grain $\mathrm{Zn}$ concentration in the embryo (89-117 mg kg-1), aleurone (34-66 mg kg-1), and endosperm (9.95-15.7 $\mathrm{mg} \mathrm{kg}^{-1}$ ).

In a recent study, Ullah et al. (2020c) characterized 16 chickpea genotypes (under field environment) for grain $\mathrm{Zn}$ biofortification potential and found that the tested genotypes have low to moderate genetic diversity and very narrow diversity for grain $\mathrm{Zn}$ concentration (37.5-48.6 $\mathrm{mg} \mathrm{kg}^{-1}$ ) and bioavailable Zn (3.72-4.42 $\mathrm{mg} \mathrm{day}^{-1}$ ). However, Rasheed et al. (2020) reported great variation for grain $\mathrm{Zn}$ and phytate concentration in lentil genotypes as the grain $\mathrm{Zn}$ and phytate concentrations ranged from 40 to 75 and 6.21 to $28.59 \mathrm{mg} \mathrm{kg}^{-1}$, respectively, while $1.49-4.02 \mathrm{mg} \mathrm{Zn} \mathrm{day}^{-1}$ estimated bioavailable $\mathrm{Zn}$ was present in grains of lentil genotypes.

In Pakistan, cultivated cereal and legume genotypes are genetically less diverse (having a narrow range of grain $\mathrm{Zn}$ and high phytate level), as currently plant breeding approaches are more focused to develop wheat, rice, and legumes varieties with high economic yield with minimal emphasis on nutritional quality (Rehman et al., 2018a; Ullah et al., 2020a,c). Moreover, uptake, translocation, and accumulation of micronutrient are governed by genetic control (Yang et al., 2007) thus, there is a need to identify genotypes having high nutrient density.

\section{Soil Related Constraints}

Plant micronutrients availability is controlled by several soil factors including soil $\mathrm{pH}$, organic matter (OM) and fertility status. Most of the Pakistani soils are developed from calcareous, alluvial deposit having high $\mathrm{pH}$, low $\mathrm{OM}$, and inherently low in plant available micronutrients. 
Soil $\mathrm{pH}$ is considered as major factor which affect the micronutrient availability and uptake. In general, soil $\mathrm{pH}$ controls the concentration, movement, solubility of ions in soil solution, and their uptake by plants (Nadeem and Farooq, 2019). Cereals cultivated on alkaline calcareous soils may experience Zn deficiency (Rehman et al., 2018a; Nadeem and Farooq, 2019). Rice-wheat cropping system (RWCS) is the major cropping system of Pakistan and most of the soils of RWCS are calcareous (rendzinas, calcisols, and calicic) (Rashid, 2006), having high soil $\mathrm{pH}, \mathrm{HCO}_{3}^{-}$, and $\mathrm{P}$ level due to flooded and puddled conditions in rice and high $\mathrm{pH}$ and chemisorption in wheat crop which lead to plant $\mathrm{Zn}$ deficiency in this cropping system (Rashid, 2006; Alloway, 2009; Rehman et al., 2018a). Similarly, legumes are mostly cultivated on sandy or marginal soil having poor Zn status (Ullah et al., 2019, 2020a). In Pakistan, around 2/3rd of agricultural soils are poor in plant available Zn (Rashid, 1996). Few years back, Maqsood et al. (2015) also reported $\mathrm{Zn}$ deficiency in 3/4th of South Punjab soils.

The success of breeding program for cereals/legumes biofortification or other crops is also dependent on the size of plant available $\mathrm{Zn}$ pools in soil. However, cereal and legumes cropping system is often practiced on high $\mathrm{pH}$, calcareous, and marginal soils, low in plant available $\mathrm{Zn}$, B, Fe (Rehman et al., 2018b; Nadeem and Farooq, 2019; Singh et al., 2020; Ullah et al., 2020a) that greatly reduce the solubility and impair root absorption of micronutrients (Cakmak, 2008). In Pakistan, most of the soils under cereals cultivation are calcareous and have low micronutrient availability thus, the genetic potential of newly developed biofortifiedcultivars to uptake sufficient $\mathrm{Zn}$ from soil and translocate it to edible part for better quality may not express to the full extent.

\section{Socio-Economic Factors}

Prices in wheat are controlled by the federal government and the food department does not give preference to certain wheat cultivars and don't pay to farmers for wheat with high nutritious value. There is no market incentive for farmers to switch the nutritious wheat cultivars with existing one; creating a significant barrier for uptake of biofortified $\mathrm{Zn}$ wheat cultivar (e.g., Zincol-2016). In general, clean, healthy and low moisture wheat is preferred for procurement by the government or private agencies. Apart from the government, there is little or no willingness among consumers to pay for nutritious food. Recently, Mahboob et al. (2020) concluded that flour cost is key factor which influence the purchasing of biofortified flour in rural and marginalized communities in Pakistan.

Farmers preference for certain traits is also one of the barriers in adoption of biofortified wheat cultivar. Zincol-2016 has higher grain $\mathrm{Zn}$ concentration, better rust resistance but have slightly lower grain yield compared to some of the widely cultivated wheat varieties (e.g., Faisalabad-2008; Zia et al., 2020). However, high nutritious value and disease resistance are not the preferred traits which determine the farmers choice of wheat cultivar; instead farmers select cultivars based on their grain yield potential, bold grain size and better chapati taste. Furthermore, provision of true to type quality seed (seed with high genetic purity) is also one of the key barriers in adoption of high $\mathrm{Zn}$ wheat varieties as a large number of the farmers in Pakistan don't use certified seed from registered seed companies or corporations due to high seed prices and lack of awareness. Many small farmers use their previous season harvested seed or exchange it with neighboring farmers and often don't have the idea of genetic purity of their cultivar.

Application of micronutrients is not widely practiced in Pakistan and the current use of $\mathrm{Zn}$ products is low. Moreover, Zn fertilizers are mostly used in Punjab and Sindh. Joy et al. (2017) estimated that annually 7,300 ton of Zn fertilizer products are applied to wheat in the country and the application rate is even below $1 \mathrm{~kg} \mathrm{ha}^{-1}$ in many districts. The major reasons for lower application of $\mathrm{Zn}$ products by farmers include the scientific knowledge gap about balance crop fertilization, lack of availability and access of quality products, high cost of $\mathrm{Zn}$ fertilizers as the subsidies from government are only focused on macronutrients ( $\mathrm{N}$ and $\mathrm{P}$ ).

\section{CONCLUSIONS}

Zinc deficiency is one of the major micronutrient malnutrition in Pakistan, particularly in children and women of reproductive age. Soil $\mathrm{Zn}$ deficiency and consumption of cereal (rice and wheat) based diets (inherently low in bioavailable $\mathrm{Zn}$ ) further exacerbates the incidence of $\mathrm{Zn}$ deficiency in crops and humans. In last decade, the research on $\mathrm{Zn}$ biofortification interventions in field crops has excelled in Pakistan and agronomic $\mathrm{Zn}$ biofortification strategy has shown promising results in enhancing the $\mathrm{Zn}$ bioavailability in field crops in Pakistan along with higher grain yield and economic returns and has potential to reduce the disease burden by saving millions of DALYs. In addition, Zn biofortified seeds helped in harvesting higher seed yield under abiotic stresses and diverse climatic conditions. Nevertheless, policies such as financial incentive to the farmers for switching to the biofortified crop cultivars; capacity building and awareness programmes for farmers, seed multipliers and rural communities to raise awareness about balance crop fertilization [macro and micronutrients (e.g., Zn)] and benefits of cultivating biofortified crop cultivars; subsidize on $\mathrm{Zn}$ fertilizer products to farmers and biofortified flours for marginalize communities are crucial for the widespread success of biofortification interventions.

\section{AUTHOR CONTRIBUTIONS}

AR and MF conceived the idea. MF and D-JL outlined the review. AR, AU, FN, SY, and SK collected the literature and prepared the first draft, while D-JL and MF reviewed the final draft. All authors contributed to the article and approved the submitted version. 


\section{REFERENCES}

Abbas, G., Hassan, G., Ali, M. A., Aslam, M., and Abbas, Z. (2010). Response of wheat to different doses of $\mathrm{ZnSO}_{4}$ under Thal desert environment. Pak J. Bot. 42, 4079-4085. Available online at: http://www.pakbs.org/pjbot/PDFs/42(6)/ PJB42(6)4079.pdf

Abid, N., Khatoon, A., Maqbool, A., Irfan, M., Bashir, A., Asif, I., et al. (2017). Transgenic expression of phytase in wheat endosperm increases bioavailability of iron and zinc in grains. Transgenic Res. 26, 109-122. doi: $10.1007 / \mathrm{s} 11248-016-9983-\mathrm{z}$

Ahsin, M., Hussain, S., Rengel, Z., and Amir, M. (2020). Zinc status and its requirement by rural adults consuming wheat from control or zinc-treated fields. Environ. Geochem. Health 42, 1877-1892. doi: 10.1007/s10653-019-00463-8

Akram, M. A., Depar, N., and Irfan, M. (2019). Zinc application improves productivity and biofortification of mini core rice hybrids: Nuclear Institute of Agriculture, Tandojam, Pakistan. Pak. J. Agri. Agric. Eng. Vet. Sci. 35, 72-80. Available online at: https://pjaaevs.sau.edu.pk/index.php/ojs/article/view/339/ 225

Alloway, B. (2008). Zinc in Soils and Crop Nutrition. 2nd Edn. Brussels: International Zinc Association; Paris: International Fertilizer Industry Association.

Alloway, B. J. (2009). Soil factors associated with zinc deficiency in crops and humans. Environ. Geochem. Health 31, 537-548. doi: 10.1007/s10653-009-9255-4

Arif, M., Waqas, M., Nawab, K., and Shahid, M. (2007). Effect of seed priming in Zn solutions on chickpea and wheat. Afr. Crop Sci. Pro. 8, 237-240. Available online at: https://www.researchgate.net/profile/Muhammad_ Arif43/publication/265825218_Effect_of_seed_priming_in_Zn_solutions_on_ chickpea_and_wheat/links/55abe5e808ae815a042af8f0.pdf

Bhowmik, D., Chiranjib, K. P., and Kumar, S. (2010). A potential medicinal importance of zinc in human health and chronic. Int. J. Pharm. 1, 5-11. Available online at: http://bergenhelse.no/wp-content/uploads/2019/06/Apotential-medicinal-importance- of-zinc-in-human-health-and-chronicdisease.pdf

Bouis, H. E., and Saltzman, A. (2017). Improving nutrition through biofortification: a review of evidence from HarvestPlus, 2003 through 2016. Glob. Food Secur. 12, 49-58. doi: 10.1016/j.gfs.2017.01.009

Cakmak, I. (2008). Enrichment of cereal grains with zinc: agronomic or genetic biofortification? Plant Soil 302, 1-17. doi: 10.1007/s11104-007-9466-3

Cakmak, I., and Kutman, U. B. (2018). Agronomic biofortification of cereals with zinc: a review. Eur. J. Soil Sci. 69, 172-180. doi: 10.1111/ejss.12437

Faran, M., Farooq, M., Rehman, A., Nawaz, A., Saleem, M. K., Ali, N., et al. (2019). High intrinsic seed $\mathrm{Zn}$ concentration improves abiotic stress tolerance in wheat. Plant Soil 437, 195-213. doi: 10.1007/s11104-019-03977-3

Farooq, M., Ullah, A., Rehman, A., Nawaz, A., Nadeem, A., Wakeel, A., et al. (2018). Application of zinc improves the productivity and biofortification of fine grain aromatic rice grown in dry seeded and puddled transplanted production systems. Field Crops Res. 216, 53-62. doi: 10.1016/j.fcr.2017.11.004

Farooq, M., Ullah, A., Usman, M., and Siddique, K. H. (2020). Application of zinc and biochar help to mitigate cadmium stress in bread wheat raised from seeds with high intrinsic zinc. Chemosphere 260:127652. doi: 10.1016/j.chemosphere.2020.127652

Farooq, M., Wahid, A., and Siddique, K. H. (2012). Micronutrient application through seed treatments: a review. J. Soil Sci. Plant Nutr. 12, 125-142. doi: $10.4067 /$ S0718-95162012000100011

Gibson, R. S. (2006). Zinc: the missing link in combating micronutrient malnutrition in developing countries. Proc. Nutr. Soc. 65, 51-60. doi: 10.1079/PNS2005474

Government of Pakistan (GOP) (2011). National Nutrition Survey 2011. Planning and Development Division. Available online at: https://pndajk.gov.pk/ uploadfiles/downloads/NNS\%20Survey.pdf (accessed July 14, 2020).

Gupta, N., Ram, H., and Kumar, B. (2016). Mechanism of Zinc absorption in plants: uptake, transport, translocation and accumulation. Rev. Environ. Sci. Biotechnol. 15, 89-109. doi: 10.1007/s11157-016-9390-1

Haider, M. U., Hussain, M., Farooq, M., and Nawaz, A. (2020). Zinc nutrition for improving the productivity and grain biofortification of mungbean. J. Soil Sci. Plant Nutr. 10, 1-5. doi: 10.1007/s42729-020-00215-z
Herschfinkel, M., Silverman, W. F., and Sekler, I. (2007). The zinc sensing receptor, a link between zinc and cell signaling. Mol. Med. 13, 331-336. doi: 10.2119/2006-00038.Hershfinkel

Hussain, S., Maqsood, M., and Miller, L. (2012b). Bioavailable zinc in grains of bread wheat varieties of Pakistan. Cereal Res. Commun. 40, 62-73. doi: 10.1556/CRC.2011.003

Hussain, S., Maqsood, M. A., Rengel, Z., and Aziz, T. (2012a). Biofortification and estimated human bioavailability of zinc in wheat grains as influenced by methods of zinc application. Plant Soil 361, 279-290. doi: 10.1007/s11104-012-1217-4

Imran, M., Kanwal, S., Hussain, S., Aziz, T., and Maqsood, M. A. (2015). Efficacy of zinc application methods for concentration and estimated bioavailability of zinc in grains of rice grown on a calcareous soil. Pak. J. Agric. Sci. 52, 169-175.

Joy, E. J. M., Ahmad, W., Zia, M. H., Kumssa, D. B., Young, S. D., Ander, E. L., et al. (2017). Valuing increased zinc (Zn) fertiliser-use in Pakistan. Plant Soil 411, 139-150. doi: 10.1007/s11104-016-2961-7

Joy, E. J. M., Stein, A. J., Young, S. D., Ander, E. L., Watts, M. J., and Broadley, M. R. (2015). Zinc-enriched fertilisers as a potential public health intervention in Africa. Plant Soil 389, 1-24. doi: 10.1007/s11104-015-2430-8

Khan, A. M., Hussain, S., Rengel, Z., and Shah, M. A. A. (2018). Zinc bioavailability and nitrogen concentration in grains of wheat crop sprayed with zinc sulfate, ammonium sulfate, ammonium chloride, and urea. J. Plant Nutr. 41, 1926-1936. doi: 10.1080/01904167.2018.1484472

Kumssa, D. B., Joy, E. J., Ander, E. L., Watts, M. J., Young, S. D., Walker, S., et al. (2015). Dietary calcium and zinc deficiency risks are decreasing but remain prevalent. Sci. Rep. 5:10974. doi: 10.1038/srep10974

Ludwig, Y., and Slamet-Loedin, I. H. (2019). Genetic biofortification to enrich rice and wheat grain iron: from genes to product. Front. Plant Sci. 10:833. doi: $10.3389 /$ fpls.2019.00833

Mahboob, U., Ohly, H., Joy, E. J., Moran, V., Zaman, M., and Lowe, N. M. (2020). Exploring community perceptions in preparation for a randomised controlled trial of biofortified flour in Pakistan. Pilot Feasibil. Stud. 6, 1-11. doi: 10.1186/s40814-020-00664-4

Maqsood, M. A., Hussain, S., Aziz, T., Ahmad, M., Naeem, A., Ahmad, H. R., et al. (2015). Zinc indexing in wheat grains and associated soils of Southern Punjab. Pak. J. Agric. Sci. 52, 431-438. Available online at: http://www.pakjas.com.pk/ papers/2433.pdf

Ministry of National Health Services Nutrition Wing (2018). National Nutritional Survey 2018, Key Finding Report. Available online at: https://www.unicef.org/ pakistan/national-nutrition-survey-2018 (accessed 12 July, 2020).

Nadeem, F., and Farooq, M. (2019). Application of micronutrients in rice-wheat cropping system of south Asia. Rice Sci. 26, 356-371. doi: 10.1016/j.rsci.2019.02.002

Nadeem, F., Farooq, M., Mustafa, B., Rehman, A., and Nawaz, A. (2020a). Residual zinc improves soil health, productivity and grain quality of rice in conventional and conservation tillage wheat-based systems. Crop Pasture Sci. 71, 322-333. doi: $10.1071 / \mathrm{CP} 19353$

Nadeem, F., Farooq, M., Ullah, A., Rehman, A., Nawaz, A., and Naveed, M. (2020b). Influence of $\mathrm{Zn}$ nutrition? grain quality and grain biofortification of wheat under conventional and conservation rice-wheat cropping systems. Arch. Agron. Soil Sci. 17, 1-6. doi: 10.1080/03650340.2019.1652273

National Institutes of Health (NIH) (2019). Iron: Fact Sheet for Consumers. Available online at: https://ods.od.nih.gov/pdf/factsheets/Iron-Consumer.pdf (accessed September 30, 2020).

Ohly, H., Broadley, M. R., Joy, E. J., Khan, M. J., McArdle, H., Zaman, M., et al. (2019). The BiZiFED project: Biofortified zinc flour to eliminate deficiency in Pakistan. Nutr. Bull. 44, 60-64. doi: 10.1111/nbu.12362

Prasad, A. S. (2007). Zinc: mechanisms of host defense. J. Nutr. 137, 1345-1349. doi: $10.1093 / \mathrm{jn} / 137.5 .1345$

Qaswar, M., Hussain, S., and Rengel, Z. (2017). Zinc fertilisation increases grain zinc and reduces grain lead and cadmium concentrations more in zincbiofortified than standard wheat cultivar. Sci. Total Environ. 605, 454-460. doi: 10.1016/j.scitotenv.2017.06.242

Rasheed, N., Maqsood, M. A., Aziz, T., and Jabbar, A. (2020). Characterizing lentil germplasm for zinc biofortification and high grain output. J. Soil Sci. Plant Nutr. 24, 1-4. doi: 10.1007/s42729-020-00216-y

Rashid, A. (1996). "Secondary and micronutrients," in Soil Science, eds A. Rashid and K. S. Memon (Islamabad: National Book Foundation), 341-386. 
Rashid, A. (2006). "Incidence, diagnosis and management of micronutrient deficiencies in crops: Success stories and limitations in Pakistan," in IFA International Workshop on Micronutrients (Kunming).

Rashid, A., Ram, H., Zou, C. Q., Rerkasem, B., Duarte, A. P., Simunji, S., et al. (2019). Effect of zinc-biofortified seeds on grain yield of wheat, rice, and common bean grown in six countries. J. Plant Nutr. Soil Sci. 182, 791-804. doi: 10.1002/jpln.201800577

Rehman, A., and Farooq, M. (2016). Zinc seed coating improves the growth, grain yield and grain biofortification of bread wheat. Acta Physiol. Plant. 38:238. doi: 10.1007/s11738-016-2250-3

Rehman, A., Farooq, M., Ahmad, R., and Basra, S. M. A. (2015). Seed priming with zinc improves the germination and early seedling growth of wheat. Seed Sci. Technol. 43, 262-268 doi: 10.15258/sst.2015.43.2.15

Rehman, A., Farooq, M., Naveed, M., Nawaz, A., and Shahzad, B. (2018b). Seed priming of $\mathrm{Zn}$ with endophytic bacteria improves the productivity and grain biofortification of bread wheat. Eur. J. Agron. 94, 98-107. doi: 10.1016/j.eja.2018.01.017

Rehman, A., Farooq, M., Naveed, M., Ozturk, L., and Nawaz, A. (2018c). Pseudomonas-aided zinc application improves the productivity and biofortification of bread wheat. Crop Pasture Sci. 69, 659-672. doi: $10.1071 / \mathrm{CP} 17441$

Rehman, A., Farooq, M., Nawaz, A., Al-Sadi, A. M., Al-Hashmi, K. S., Nadeem, F., et al. (2018d). Characterizing bread wheat genotypes of Pakistani origin for grain zinc biofortification potential. J. Sci. Food Agric. 98, 4824-4836. doi: 10.1002/jsfa.9010

Rehman, A., Farooq, M., Ozturk, L., Asif, M., and Siddique, K. H. M. (2018a). Zinc nutrition in wheat-based cropping systems. Plant Soil 422, 283-315. doi: 10.1007/s11104-017-3507-3

Singh, D., Geat, N., Rajawat, M. V. S., Prasanna, R., and Saxena, A. K. (2020). Performance of low and high Fe accumulator wheat genotypes grown on soils with low or high available Fe and endophyte inoculation. Acta Physiol. Plant 42:24. doi: 10.1007/s11738-019-2997-4

Tripathi, D. K., Singh, S., Singh, S., Mishra, S., Chauhan, D. K., and Dubey, N. K. (2015). Micronutrients and their diverse role in agricultural crops: advances and future prospective. Acta Physiol. Plant 37:139. doi: $10.1007 /$ s11738-015-1870-3

Ullah, A., Al-Sadi, A. M., Al-Subhi, A. M., and Farooq, M. (2020c). Characterization of chickpea genotypes of Pakistani origin for genetic diversity and zinc grain biofortification. J. Sci. Food Agric. 100, 4139-4149. doi: $10.1002 /$ jsfa. 10453

Ullah, A., Farooq, M., and Hussain, M. (2019). Improving the productivity, profitability and grain quality of kabuli chickpea with coapplication of zinc and endophyte bacteria Enterobacter sp. MN17. Arch. Agron. Soil. Sci. 25, 1-6. doi: 10.1080/03650340.2019.1644501

Ullah, A., Farooq, M., Nadeem, F., Rehman, A., Hussain, M., Nawaz, A., et al. (2020d). Zinc application in combination with zinc solubilizing Enterobacter sp. MN17 improved productivity, profitability, zinc efficiency, and quality of desi chickpea. J. Soil Sci. Plant Nutr. 25, 1-2. doi: 10.1007/s42729-020-00281-3

Ullah, A., Farooq, M., Nadeem, F., Rehman, A., Nawaz, A., Naveed, M., et al. (2020e). Zinc seed treatments improve productivity, quality and grain biofortification of desi and kabuli chickpea (Cicer arietinum). Crop Pasture Sci. 71, 668-678. doi: 10.1071/CP19266

Ullah, A., Farooq, M., Rehman, A., Hussain, M., and Siddique, K. H. M. (2020a). Zinc nutrition in chickpea (Cicer arietinum): a review. Crop Pasture Sci. 71, 199-218. doi: 10.1071/CP19357
Ullah, A., Shah, T. M., and Farooq, M. (2020b). Pulses production in pakistan: status, constraints and opportunities. Int. J. Plant Prod. 6, 1-21. Available online at: https://link.springer.com/article/10.1007/s42106-020-00108-2

Umar, W., Hameed, M. K., Aziz, T., Maqsood, M. A., Bilal, H. M., and Rasheed, N. (2020). Synthesis, characterization and application of $\mathrm{ZnO}$ nanoparticles for improved growth and Zn biofortification in maize. Arch. Agron. Soil Sci. doi: 10.1080/03650340.2020.1782893. [Epub ahead of print].

UNICEF (2020). Global Nutrition Report. Available online at https:// globalnutritionreport.org/reports/2020-global-nutrition-report/ (accessed October 10, 2020).

Wasaya, A., Shahzad Shabir, M., Hussain, M., Ansar, M., Aziz, A., Hassan, W., et al. (2017). Foliar application of zinc and boron improved the productivity and net returns of maize grown under rainfed conditions of Pothwar plateau. J. Soil Sci. Plant Nutr. 17, 33-45. doi: 10.4067/S0718-95162017005000003

Wessels, I., and Rink, L. (2020). Micronutrients in autoimmune diseases: possible therapeutic benefits of zinc and vitamin D. J. Nutri. Biochem. 77:108240. doi: 10.1016/j.jnutbio.2019.108240

White, P. J., and Broadley, M. R. (2005). Biofortifying crops with essential mineral elements. Trends Plant Sci. 10, 586-593. doi: 10.1016/j.tplants.2005. 10.001

Yang, X. E., Chen, W. R., and Feng, Y. (2007). Improving human micronutrient nutrition through biofortification in the soil-plant system: China as a case study. Environ. Geochem. Health 29, 413-428. doi: 10.1007/s10653-0079086-0

Yaseen, M. K., and Hussain, S. (2020). Zinc-biofortified wheat required only a medium rate of soil zinc application to attain the targets of zinc biofortification. Arch. Agron. Soil Sci. 14, 1-2. doi: 10.1080/03650340.2020. 1739659

Yilmaz, A., Ekiz, H., Gültekin, I., Torun, B., Barut, H., Karanlik, S., et al. (1998). Effect of seed zinc content on grain yield and zinc concentration of wheat grown in zinc deficient calcareous soils. J. Plant Nutr. 21, 2257-2264. doi: 10.1080/01904169809365559

Yousaf, S., Akhtar, M., Sarwar, N., Ikram, W., and Hussain, S. (2019). Sustaining zinc bioavailability in wheat grown on phosphorus amended calcisol. J. Cereal Sci. 90:102846. doi: 10.1016/j.jcs.2019. 102846

Zia, M. H., Ahmed, I., Bailey, E. H., Lark, R. M., Young, S. D., Lowe, N. M., et al. (2020). Site-specific factors influence the field performance of a $\mathrm{Zn}$-biofortified wheat variety. Front. Sustain. Food Syst. 4, 1-13. doi: 10.3389/fsufs.2020. 00135

Zuo, Y., and Zhang, F. (2009). Iron and zinc biofortification strategies in dicot plants by intercropping with gramineous species. a review. Agron Sustain. Dev. 29, 63-71. doi: 10.1051/agro:2008055

Conflict of Interest: The authors declare that the research was conducted in the absence of any commercial or financial relationships that could be construed as a potential conflict of interest.

Copyright (c) 2020 Rehman, Farooq, Ullah, Nadeem, Im, Park and Lee. This is an open-access article distributed under the terms of the Creative Commons Attribution License (CC BY). The use, distribution or reproduction in other forums is permitted, provided the original author(s) and the copyright owner(s) are credited and that the original publication in this journal is cited, in accordance with accepted academic practice. No use, distribution or reproduction is permitted which does not comply with these terms. 